\title{
PATHOGEN-SPECIFIC ANTIBODY PROFILES IN PATIENTS WITH SEVERE SYSTEMIC INFECTIONS
}

\author{
N. Normann ${ }^{1}$, G. Tietz ${ }^{1}$, A. Kühn' ${ }^{2}$ C. Fuchs' ${ }^{2}$ V. Balau ${ }^{3}$, K. Schulz ${ }^{3}$, J. Kolata ${ }^{1}$, T. Schuerholz ${ }^{4}$, \\ A. Petersmann ${ }^{5}$, S. Stentzel ${ }^{1}$, L. Steil ${ }^{6}$, S.O. Kuhn², K. Meissner ${ }^{2}$, U. Völker ${ }^{6}$, M. Nauck ${ }^{5}$, I. Steinmetz ${ }^{3}$, \\ D. Raafat ${ }^{1,7}$, M. Gründling ${ }^{2}$ and B.M. Bröker ${ }^{1, *}$ \\ ${ }^{1}$ Department of Immunology, University Medicine Greifswald, Greifswald, Germany \\ ${ }^{2}$ Department of Anaesthesiology and Intensive Care Medicine, University Medicine Greifswald, \\ Greifswald, Germany \\ ${ }^{3}$ Friedrich-Loeffler-Institute of Medical Microbiology, University Medicine Greifswald, \\ Greifswald, Germany \\ ${ }^{4}$ Department of Anaesthesiology and Intensive Care Medicine, University Hospital Rostock, \\ Rostock, Germany \\ ${ }^{5}$ Institute of Clinical Chemistry and Laboratory Medicine, University Medicine Greifswald, \\ Greifswald, Germany \\ ${ }^{6}$ Department of Functional Genomics, University Medicine Greifswald, Greifswald, Germany \\ ${ }^{7}$ Department of Microbiology and Immunology, Faculty of Pharmacy, Alexandria University, \\ Alexandria, Egypt
}

\begin{abstract}
Infections are often caused by pathobionts, endogenous bacteria that belong to the microbiota. Trauma and surgical intervention can allow bacteria to overcome host defences, ultimately leading to sepsis if left untreated. One of the main defence strategies of the immune system is the production of highly specific antibodies. In the present proof-of-concept study, plasma antibodies against 9 major pathogens were measured in sepsis patients, as an example of severe systemic infections. The binding of plasma antibodies to bacterial extracellular proteins was quantified using a semi-automated immunoblot assay. Comparison of the pathogen-specific antibody levels before and after infection showed an increase in plasma IgG in 20 out of 37 tested patients. This host-directed approach extended the results of pathogen-oriented microbiological and PCR diagnostics: a specific antibody response to additional bacteria was frequently observed, indicating unrecognised polymicrobial invasion. This might explain some cases of failed, seemingly targeted antibiotic treatment.
\end{abstract}

Keywords: Systemic infection, sepsis, pathogen-specific IgG, serology, antibody response.

*Address for correspondence: Prof. Dr med. Barbara M. Bröker, University Medicine Greifswald, Institute of Immunology and Transfusion Medicine, Department of Immunology, Ferdinand-Sauerbruch-Strasse DZ7, D-17475 Greifswald, Germany.

Telephone number: +49 3834865595 Email: broeker@uni-greifswald.de

Copyright policy: This article is distributed in accordance with Creative Commons Attribution Licence (http://creativecommons.org/licenses/by-sa/4.0/).

\section{Introduction}

Bacteria, commensals as well as pathogens, are constantly surrounding the human body, frequently as members of the microbiota. The innate and adaptive immune systems are responsible for preventing these bacteria from penetrating the protective barrier of skin and mucous membranes, e.g. through the production of specific (neutralising) antibodies (Byrd et al., 2018). Favoured by trauma and invasive surgical procedures, these endogenous opportunistic pathogens, also referred to as pathobionts, can occasionally cause severe infections, ranging from bone and soft tissue infections to implant-associated infections, up to sepsis (Benito et al., 2019). Sepsis, defined as a 'life-threatening organ dysfunction caused by a dysregulated host response to infection' (Singer et al., 2016), is a leading cause of death (Fleischmann et al., 2015; La Suarez De Rica et al., 2016). Sepsis caused by Staphylococcus aureus (S. aureus) induces a strain-specific IgG response. An increase in anti-S. aureus antibodies in patient 
sera during an infection is observed in most patients, often in the early stages of the disease (Kolata et al., 2011). This suggests that studying the adaptive immune system's reaction to bacterial invasion could shed light on the infection process, complementing pathogen-directed techniques such as microbiological culture and PCR methods.

Positive microbial culture provides clinicians with information about the identity as well as antibiotic susceptibility of the causative bacterial species and, hence, guides a subsequent antibiotic treatment that is lifesaving (Dellinger et al., 2013; Kim and Park, 2019). However, up to $70 \%$ of all clinically diagnosed sepsis cases are culture-negative (Cohen et al., 2015), showing that standard microbiological culture lacks sensitivity. Moreover, standard microbiological culture is vulnerable to antibiotic treatment and sampling error (false positive or false negative), especially in the setting of poly-microbial infections. On the other hand, sequence-based pathogen detection by PCR allows for faster and more sensitive pathogen diagnostics (Trung et al., 2019) despite being often unable to determine whether the pathogen is actually responsible for the infection, leading to false positives (poor specificity) (Yamamoto, 2002).

Pathogens that induce an adaptive immune response are probably relevant in the infection process and may be identified by measuring pathogen-specific IgGs in the blood. Such a hostdirected approach would be robust against antibiotic therapy. However, the interpretation of the antibody levels is complicated by the fact that many sepsiscausing agents are members of the human microbiota. Therefore, the individual history of exposure to these pathobionts results in highly variable basal pathogenspecific plasma antibody levels, precluding the definition of a "diagnostic threshold" (Hornef, 2015). Studies have previously shown that IgG titers against certain $S$. aureus proteins have a diagnostic value in different clinical settings, including osteomyelitis, diabetic foot infections, epidermolysis bullosa and prosthetic joint infections (PJI) (Marmor et al., 2016; Nishitani et al., 2015; Oh et al., 2018; van der KooiPol et al., 2013). Moreover, high basal anti-S. aureus antibody titers show protection against severe S. aureus infections/complications (Fritz et al., 2013; Michalik et al., 2020; Stentzel et al., 2015). However, little is known about the diagnostic potential of the antibody response against other frequent nosocomial pathogens.

The measurement of increases in specific antibody levels during infection, as they are consistently observed in patients with $S$. aureus bacteraemia (Kolata et al., 2011), could also be of value in infections caused by other bacterial pathogens. The present proof-of-concept study demonstrated that sepsis patients developed an IgG response, which was specific for the invasive pathogen(s). This approach might complement pathogen-directed diagnosis, especially of secondary and poly-microbial infections.

\section{Materials and Methods}

\section{Study design and patient material}

Within a prospective clinical trial, 52 sepsis patients, fulfilling the 2001 consensus definition of severe sepsis or septic shock, were recruited at the University Medicine Greifswald between 2011 and 2012 (Levy et al., 2003). The study was approved by the institutional ethics committee of the University Medicine Greifswald (VYOO Amendment, BB138/10a). All patients provided written informed consent for study participation. Around $71 \%$ of those sepsis patients ( $n=37 ; 24$ male and 13 female; age range: $28-85$ years; median: 72 years) had a standard microbiological diagnosis based on blood cultures $(n=17)$ or respective sites of infection $(n=20)$ and were, thus, included in the study (for further information on the patient cohort consult Table 1). Results of a multiplex PCR test (VYOO) for the detection of pathogens in blood taken at sepsis diagnosis were available for 16 of the 37 patients investigated in the study (Sachse et al., 2009). Among those 16 patients, $81 \%(13 / 16)$ showed concordance with the microbiological findings. Moreover, poly-microbial infections were detected in $35 \%$ and $24 \%$ of the patients, by microbiology and PCR, respectively. 23 of the 37 patients $(62.2 \%)$ presented with serum lactate levels $>2 \mathrm{mmol} / \mathrm{L}$, fulfilling the sepsis-3 definition criterion for septic shock (Singer et al., 2016). For each patient, two plasma samples were analysed, with a median time span $(\Delta \mathrm{T})$ of $16 \mathrm{~d}$. For the earlier time point, blood was obtained either at the time of clinical diagnosis of sepsis $(n=37)$ or, whenever possible, at a time point before sepsis diagnosis $(n=35)$. This was possible because diagnostic samples are routinely stored for $6 \mathrm{~d}$ at the Institute of Clinical Chemistry and Laboratory Medicine, University Medicine Greifswald, Greifswald, Germany. These reserved diagnostic samples were made available for the present study and used to determine basal plasma antibody levels. The second patient sample was taken at the latest possible time point during infection. Two plasma samples from each of 8 healthy control subjects [ 5 male $(62.5 \%)$ and 3 female $(37.5 \%)$ ], with a median $\Delta \mathrm{T}$ of $20 \mathrm{~d}$, were likewise analysed.

\section{Bacterial cultivation and protein extraction}

The bacterial strains isolated from positive blood cultures or other samples taken from sites of infection were stored as glycerol stocks at $-80{ }^{\circ} \mathrm{C}$. For the antigen preparation, overnight cultures of the respective bacterial strains in tryptic soy broth (TBS, Oxoid Ltd, Cheshire, UK) were used to inoculate the main culture to an optical density (OD) at $595 \mathrm{~nm}$ of 0.05 . The cultures were grown at $37^{\circ} \mathrm{C}$ and 100 shakes per min (spm) for a total of $8 \mathrm{~h}$. The culture supernatants were harvested and the secreted proteins extracted as previously described (Holtfreter et al., 2009). Briefly, the culture supernatant was filtered through a $0.2 \mu \mathrm{m}$ membran (Merck). 
Table 1. Baseline characteristics of the sepsis patient cohort included in the study $(n=37) .{ }^{1} \mathrm{~m}$, male; $\mathrm{f}$, female. ${ }^{2} \mathrm{~B}$, primary bacteraemia; $\mathrm{B} / \mathrm{ST}$, bone and soft tissue infection; $\mathrm{C}$, catheter-associated infection; IA, intraabdominal infection; $\mathrm{P}$, pneumonia; $\mathrm{U}$, urinary tract infection. ${ }^{3}$ Septic shock was defined according to the Sepsis-3 definition by serum lactate levels $>2 \mathrm{mmol} / \mathrm{L}$ (Singer et al., 2016). ${ }^{4} 90$-d survival. ${ }^{5} \mathrm{~A}$, abscess; $\mathrm{C}$, catheter; $\mathrm{DF}$, drain fluid; N, nose; $\mathrm{P}$, perineum; $\mathrm{T}$, tracheal secretion; $\mathrm{W}$, wound. ${ }^{*}$ E. faecium; E. faecalis. ${ }^{+}$for two patients no serum lactate levels were available. CoNS: coagulase-negative staphylococci; nd: not determined.

\begin{tabular}{|c|c|c|c|c|c|c|c|c|}
\hline \multicolumn{6}{|c|}{ Patient characteristics } & \multicolumn{2}{|c|}{ Microbiological findings } & \multirow{2}{*}{$\begin{array}{c}\text { PCR results } \\
\text { VYOO }^{\circledR}\end{array}$} \\
\hline ID & Age & Sex $^{1}$ & $\begin{array}{l}\text { Infection } \\
\text { focus }^{2}\end{array}$ & Diagnosis $^{3}$ & Survival $^{4}$ & Blood culture & Other material $^{5}$ & \\
\hline 1 & 58 & $\mathrm{~m}$ & IA & sepsis $^{+}$ & yes & S. haemolyticus & $\begin{array}{l}\text { Enterococci }{ }^{\mathrm{W}, *} ; \\
\text { C. }_{\text {albicans }}{ }^{\mathrm{W}} \\
\end{array}$ & $\begin{array}{l}\text { B. fragilis; CoNS; } \\
\text { E. faecium }\end{array}$ \\
\hline 2 & 55 & $\mathrm{~m}$ & IA & sepsis & no & & E. faecium $^{\mathrm{W}}$ & CoNS; E. faecium \\
\hline 3 & 76 & $\mathrm{~m}$ & nd & septic shock & no & S. aureus & S. aureus $^{\mathrm{T}}$ & S. aureus \\
\hline 7 & 84 & $\mathrm{f}$ & IA & septic shock & no & & E. faecium $^{\mathrm{w}}$ & E. faecium \\
\hline 8 & 65 & $\mathrm{~m}$ & $\mathrm{~B} / \mathrm{ST}$ & septic shock & no & & $\begin{array}{l}\text { S. epidermidis }{ }^{\mathrm{W}} ; \mathrm{CoNS}^{\mathrm{T}} ; \\
\text { Candida species }^{\mathrm{T}}\end{array}$ & S. aureus \\
\hline 10 & 81 & $\mathrm{f}$ & $\mathrm{P}$ & septic shock & no & E. coli & C. albicans ${ }^{\mathrm{N}, \mathrm{P}}$ & E. coli \\
\hline 11 & 72 & $\mathrm{~m}$ & IA & sepsis & yes & & S. aureus ${ }^{\mathrm{N}, \mathrm{P}}$ & \\
\hline 12 & 50 & $\mathrm{~m}$ & IA & septic shock & yes & & E. faecalis $^{\mathrm{W}}$; C. albicans ${ }^{\mathrm{W}}$ & \\
\hline 13 & 57 & $\mathrm{f}$ & nd & septic shock & yes & S. hominis & & \\
\hline 14 & 52 & $\mathrm{f}$ & IA & sepsis & nd & & E. coli ${ }^{\mathrm{P}, \mathrm{DF}}$ & \\
\hline 15 & 40 & $\mathrm{f}$ & $\mathrm{P}$ & septic shock & yes & $\begin{array}{l}\text { S. pneumoniae; } \\
\text { S. hominis }\end{array}$ & & \\
\hline 16 & 28 & $\mathrm{~m}$ & IA & sepsis & nd & $\begin{array}{l}\text { S. haemolyticus; } \\
\text { S. epidermidis }\end{array}$ & S. aureus ${ }^{\mathrm{W}}$ & \\
\hline 17 & 78 & $\mathrm{f}$ & IA & septic shock & yes & & E. faecium $^{\mathrm{A}}$ & \\
\hline 18 & 72 & $\mathrm{f}$ & $\mathrm{P}$ & sepsis & nd & $\begin{array}{c}\text { C. glabrata; } \\
\text { S. epidermidis }\end{array}$ & A. hydrophila/caviae ${ }^{\mathrm{w}}$ & \\
\hline 21 & 60 & $\mathrm{~m}$ & IA & septic shock & no & & E. coli ${ }^{\mathrm{W}}$ & E. coli; CoNS \\
\hline 22 & 56 & $\mathrm{~m}$ & IA & sepsis & nd & $\begin{array}{l}\text { S. haemolyticus; } \\
\text { E. faecalis }\end{array}$ & $\begin{array}{c}\text { S. haemolyticus } \\
\text { E. faecalis } \\
\end{array}$ & \\
\hline 24 & 78 & $\mathrm{~m}$ & IA & septic shock & nd & & $\begin{array}{c}\text { K. pneumoniae }{ }^{\mathrm{w}} ; \\
\text { E. } \text { coli }^{\mathrm{w}} ; \text { E. }_{\text {aecalis }} \mathrm{w}\end{array}$ & \\
\hline 25 & 85 & $\mathrm{f}$ & $\mathrm{P}$ & septic shock & no & & Enterococci ${ }^{\mathrm{W}, *}$ & \\
\hline 26 & 77 & $\mathrm{~m}$ & $\mathrm{~B} / \mathrm{ST}$ & sepsis & yes & S. schleiferi & S. aureus $\mathrm{N}^{\mathrm{N}}$ & S. aureus \\
\hline 27 & 73 & $\mathrm{~m}$ & IA & septic shock & yes & E. faecalis & & E. coli; CoNS; E. faecium \\
\hline 28 & 77 & $\mathrm{~m}$ & B & septic shock & yes & $\begin{array}{c}\text { E. faecalis; } \\
\text { S. epidermidis }\end{array}$ & & \\
\hline 29 & 81 & $\mathrm{~m}$ & IA & septic shock & nd & & E. coli & E. coli; CoNS \\
\hline 31 & 68 & $\mathrm{~m}$ & $\mathrm{P}$ & sepsis & yes & & $\begin{array}{c}\text { Streptococci }{ }^{\mathrm{T}} \text {; } \text { CoNS }^{\mathrm{T}} ; \\
\text { E. coli }\end{array}$ & \\
\hline 32 & 51 & $\mathrm{~m}$ & IA & septic shock & nd & K. pneumoniae & & \\
\hline 34 & 78 & $\mathrm{f}$ & $\mathrm{B} / \mathrm{ST}$ & septic shock & no & & S. aureus $^{\mathrm{W}}$ & \\
\hline 35 & 75 & $\mathrm{~m}$ & nd & sepsis & yes & & K. pneumoniae ${ }^{\mathrm{C}}$ & \\
\hline 36 & 44 & $\mathrm{~m}$ & nd & sepsis $^{+}$ & nd & S. marcescens & & \\
\hline 41 & 49 & $\mathrm{~m}$ & IA & septic shock & yes & & E. faecium ${ }^{\mathrm{W}, \mathrm{T}, \mathrm{DF}}$ & $\begin{array}{l}\text { B. fragilis; E. faecium; } \\
\text { P. mirabilis }\end{array}$ \\
\hline 43 & 76 & $\mathrm{f}$ & $\mathrm{P}$ & sepsis & nd & & K. oxytoca ${ }^{\mathrm{T}, \mathrm{C}}$ & S. aureus \\
\hline 45 & 46 & $\mathrm{f}$ & IA & septic shock & yes & & $\begin{array}{l}\text { P. mirabilis }{ }^{\mathrm{W}} \text {; } \\
\text { Enterococi }^{\mathrm{W}}\end{array}$ & $\begin{array}{l}\text { E. coli; E. faecium; } \\
\text { K. oxytoca }\end{array}$ \\
\hline 46 & 68 & $\mathrm{~m}$ & nd & septic shock & no & P. aeruginosa & P. aeruginosa ${ }^{\mathrm{T}}$ & B. fragilis; $P$. aeruginosa \\
\hline 47 & 54 & $\mathrm{~m}$ & $\mathrm{U}$ & septic shock & yes & & Enterococci $^{\mathrm{T}, \mathrm{C}, *}$ & \\
\hline 48 & 75 & $\mathrm{~m}$ & $\mathrm{~B} / \mathrm{ST}$ & sepsis & yes & S. aureus & S. aureus $^{\mathrm{W}}$ & S. aureus \\
\hline 50 & 81 & $\mathrm{f}$ & IA & septic shock & nd & & $\begin{array}{c}\text { Enterococci }^{\mathrm{W}, *} \\
\text { P. mirabilis } \\
\mathrm{W}\end{array}$ & $\begin{array}{c}\text { Enterococci*; } \\
\text { P. mirabilis; C. glabrata }\end{array}$ \\
\hline 51 & 81 & $\mathrm{~m}$ & IA & sepsis & yes & S. epidermidis & $\begin{array}{l}{\text { E. } \text { faecium }^{\mathrm{w}} \text {; C. freundii }}^{\mathrm{w}} \text {; } \\
\text { Bacteroides spp. }{ }^{\mathrm{w}} ; \\
\text { C. albicans }{ }^{\mathrm{w}}\end{array}$ & \\
\hline 53 & 80 & $\mathrm{~m}$ & IA & septic shock & yes & & P. aeruginosa ${ }^{\mathrm{C}}$ & \\
\hline 54 & 70 & $\mathrm{f}$ & IA & septic shock & yes & $\begin{array}{l}\text { S. haemolyticus; } \\
\text { E. coli }\end{array}$ & & \\
\hline
\end{tabular}


Table 2. Settings for immunoblot assays. Group 1 bacteria are the most common sepsis pathogens. Group 2 bacteria were used for a personalised approach in selected cases.

\begin{tabular}{|c|c|c|}
\hline Sample & \multicolumn{2}{|c|}{ Dilution } \\
\hline $\begin{array}{c}\text { Exoproteomes of the following bacterial } \\
\text { species (final concentration: } \mathbf{1} \text { mg/mL) }\end{array}$ & $\begin{array}{c}\text { Primary antibody } \\
\text { (plasma) }\end{array}$ & $\begin{array}{c}\text { Detection antibody (anti- } \\
\text { human IgG POD) }\end{array}$ \\
\hline Group 1 & $1: 2,000$ \\
\hline Enterococcus faecium & $1: 2,000$ \\
\hline Escherichia coli & $1: 2,000$ \\
\hline Serratia marcescens & $1: 2,000$ \\
\hline Pseudomonas aeruginosa & $1: 2,000$ \\
Klebsiella pneumoniae & $1: 1,000$ \\
\hline Streptococcus pneumoniae & $1: 2,000$ \\
\hline Staphylococcus aureus & $1: 10,000$ \\
\hline Staphylococcus epidermidis & $1: 4,000$ \\
\hline Staphylococcus haemolyticus & $1: 4,000$ \\
\hline Group 2 & $1: 1,000$ \\
\hline Staphylococcus hominis & $1: 1,000$ \\
\hline Enterococcus faecalis & $1: 2,000$ \\
\hline Proteus mirabilis & $1: 2,000$ \\
\hline Klebsiella oxytoca & $1: 1,000$ \\
\hline Tetanus toxoid (final concentration: $0.2 \mathrm{mg} / \mathrm{mL}$ ) & $1: 1,000$ \\
\hline
\end{tabular}

The secreted proteins were precipitated using trichloroacetic acid (TCA, Roth; final concentration $10 \%)$, washed with $70 \%$ ethanol and resolved in rehydration buffer containing $8 \mathrm{M}$ urea (Merck), $2 \mathrm{M}$ thiourea (Merck) and $2 \%$ 3-((3-cholamidopropyl) dimethylammonio)-1-propanesulphonate (CHAPS; Merck). Protein concentrations were measured using the Bradford Protein Assay (Bio-Rad) (Bradford, 1976). The purified protein samples were stored at $-80^{\circ} \mathrm{C}$.

For $S$. aureus, the protein-A-deficient mutant of strain USA300 (S. aureus USA300Aspa; Stentzel et al., 2015) was used to prevent non-specific antibody binding. Moreover, staphylococci were cultured under iron limitation, namely in TSB supplemented with 2,2'-bipyridyl (Sigma-Aldrich; final concentration $600 \mu \mathrm{M})$, to enhance the secretion of immunogenic proteins (Stentzel et al., 2014).

\section{Semi-automated immunoblot assay}

Antibody binding to extracellular proteins of common sepsis pathogens as well as tetanus toxoid (TT, Statens Serum Institute, Copenhagen, Denmark) was quantified using semi-automated quantitative immunoblotting (Peggy Sue ${ }^{\mathrm{TM}}$ Simple Western Assay; ProteinSimple ${ }^{\circledast}$, Santa Clara, CA, USA), which uses capillary electrophoresis for antigen separation followed by exposure to the antibody samples and quantification of antibody binding by chemiluminescence. Two plasma samples per study subject were analysed, one obtained at the earliest and one at the latest available time point. Antigen-specific plasma antibodies were measured according to the Peggy Sue ${ }^{\mathrm{TM}}$ Simple Western Assay manual (Kit: 12-230 kDa Peggy Sue ${ }^{\mathrm{TM}}$ or Sally Sue ${ }^{\mathrm{TM}}$ Separation Module SM-S001 and DM-003) using $1 \mathrm{mg} / \mathrm{mL}$ and $0.2 \mathrm{mg} / \mathrm{mL}$ of extracellular proteins and TT, respectively. In brief, bacterial proteins were mixed with $5 \times$ mastermix containing sample buffer, DTT and a fluorescent standard. Protein samples and biotinylated molecular weight (MW) standards from ProteinSimple ${ }^{\circledR}$ were heated for 5 min at $95{ }^{\circ} \mathrm{C}$. Human plasma samples served as the source of primary antibodies and their dilution was optimised for each bacterial species $(1: 1,000$ to $1: 10,000)$ (Table 2). The polyclonal detection antibody [goat anti-human IgG $(\mathrm{H}+\mathrm{L})$ horse-radishperoxidase (POD)-conjugated; 109-035-088, Dianova, Hamburg, Germany] was used at a final concentration of $0.8 \mathrm{ng} /$ $\mathrm{mL}$. The different reagents, including protein samples, blocking reagent, diluted plasma samples, detection antibody, chemiluminescent substrate, separation and stacking matrices were loaded to designated wells in a 384-well plate. The plate was loaded into the instrument and separation as well as detection steps were performed automatically, analogous to standard immunoblotting procedures. The chemiluminescence signals generated upon reaction 
with a luminol/peroxide substrate solution were displayed as electropherograms and automatically analysed using Compass for SW software Version 3.1.7 (ProteinSimple ${ }^{\circledR}$ ). The areas under the curve of manually set peaks (peak fit width, 2; baseline, 0 ; area calculation, Gaussian fit) were summed to obtain the total signal. Data were analysed and visualised using GraphPadPrism Version 6 (GraphPad Software). The increase in pathogen-specific IgG was determined by comparing plasma antibody binding during sepsis with that prior to infection. To exclude non-specific $B$ cell activation in the study cohort, plasma antibody binding to the recall antigen TT was also measured at both time points.

\section{Statistical analysis}

The statistical analysis was performed using GraphPad Prism Version 6. To compare changes in plasma IgG binding in healthy subjects and sepsis patients, the data were analysed using the unpaired t-test. $p \leq 0.05$ was considered statistically significant.

\section{Results}

Basal levels of pathogen-specific plasma IgG binding in healthy subjects showed substantial inter-individual and inter-species variations (Fig. 1). However, binding of plasma IgG to TT or to the extracellular proteins of the 9 most common sepsis-causing bacteria (listed in Table 2, group 1) did not change significantly over time (mean $=0.9$ fold; $\Delta \mathrm{T}=20 \mathrm{~d}$; Fig. 2). Therefore, the threshold for a significant rise in antibody binding was set, based on results from healthy subjects, to a 1.6-fold increase $[$ mean $+3 \times$ standard deviation $(\mathrm{SD})]$.
When tested for increase in IgG binding to the microbiologically diagnosed infectious agents, the microbiological diagnosis was corroborated in 20 out of 37 sepsis patients (54\%) (Fig. 2, $\Delta \mathrm{T}=16 \mathrm{~d}$ ). In contrast, the anti-TT antibody levels remained stable in most of the patients as already observed for the healthy control group. However, due to one outlier (patient 28), the mean concentration of plasma antibodies against the recall antigen TT increased slightly in the sepsis patient group (Fig. 2).

To assess the specificity of the anti-bacterial responses, patients showing an increase in pathogenspecific antibody binding were further analysed for their antibody responses to the 9 most frequently diagnosed bacterial species. 3 groups of patients could be distinguished (Fig. 3, Table 3).

- In 4 patients, IgG binding to a single pathogen, also identified in the blood culture, increased significantly (9- to 37-fold) and in two cases, patient 10 and 46 , the result was additionally confirmed by PCR (Fig. 3a, Table 3). Together with the lack of significant changes in the anti-TT titers, this confirmed that the antibody responses were caused by the invasive bacteria.

- In 15 patients, most of whom suffered intraabdominal infections, antibody responses to additional pathogens were observed. 5 of those patients exhibited only minor increases in IgG levels (1.6- to 5-fold). In 9 of the 15 patients, the strongest increase in plasma antibodies was directed against the microbiologically diagnosed pathogen (Fig. 3b, Table 3). In the remaining 6 cases bacteria other than the microbiologically diagnosed ones elicited a stronger IgG response (Fig. 3c, Table 3). In patient 41, for example, E. faecium was identified by both microbiology

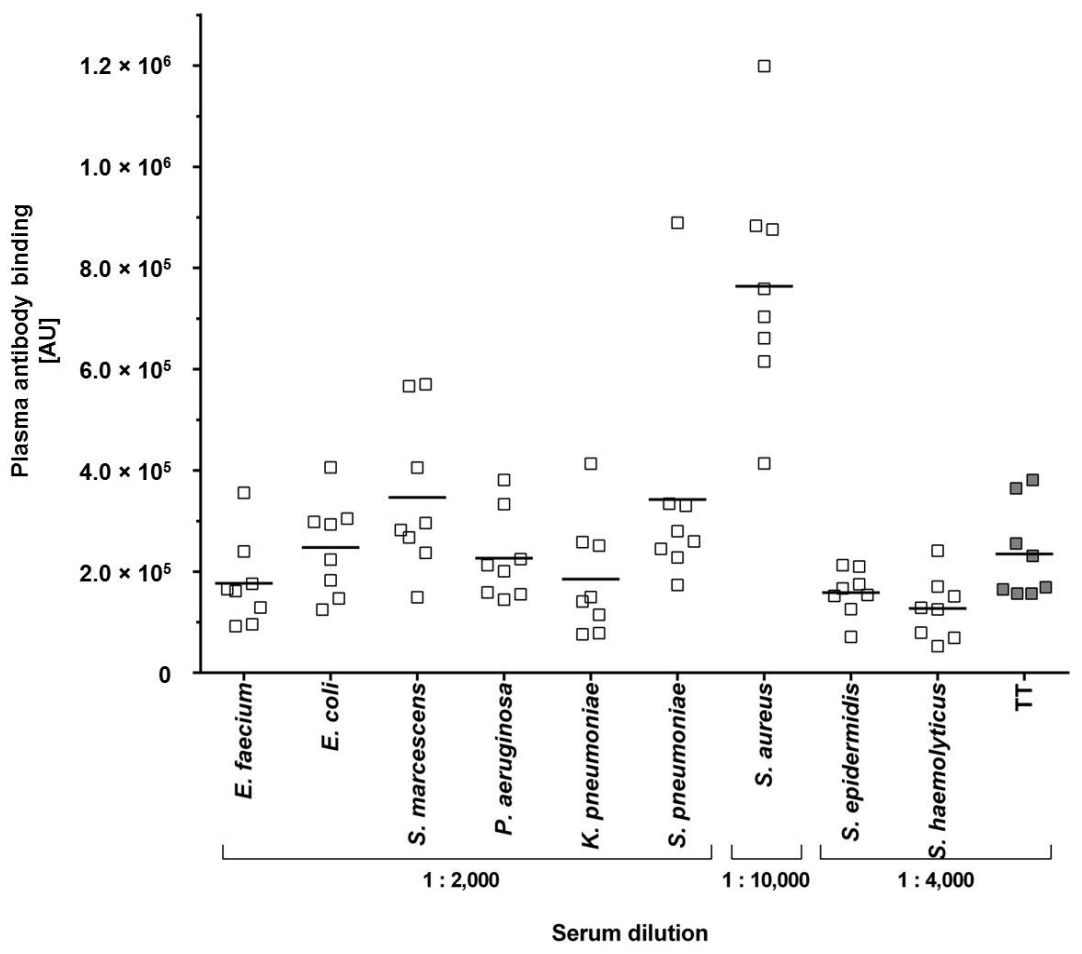

Fig. 1. Basal pathogen-specific plasma IgG levels in healthy subjects. Plasma IgG binding to extracellular proteins of frequent sepsis pathogens was quantified using semi-automated quantitative immunoblotting. TT served as a control antigen (grey squares). Plasma samples were diluted between 1 : 2,000 and $1: 10,000$, as indicated, to ensure measurement within the linear range of the assay (Table 2). The area under the curve of manually set peaks was calculated using Compass SW Version 3.1.7. All signals were added to obtain the total signal of antibody binding (AU, arbitrary units). Squares show the mean values of two replicates; means are indicated. 
and PCR, whereas the increase in IgG binding against $S$. marcescens exceeded the increase against $E$. faecium by more than 10 -fold.

- In 1 patient, a pronounced increase in anti-TT antibodies exceeded the pathogen-specific responses; however, the minor increases against enterococci and S. epidermidis were still consistent with the microbiological findings (patient 28, Table 3).

In 21 of the 37 patients examined, no pathogen could be identified by PCR. Interestingly, 17 of these patients showed only minor increases in IgG levels ( $\leq 5$-fold). Of the 16 patients with positive PCR results, the pathogen diagnosis result was concordant with the observed antibody increase in 9 cases (56\%). Similarly, the serological approach was often able to identify other or additional pathogens when compared to PCR. In 4 PCR-negative patients (patients $14,15,36$ and 51, Table 1) a possible causative agent could be diagnosed with the serological approach used.

\section{Discussion}

Serological assays are widely used in disease diagnostics, but typically employ (single/multiple) well-defined recombinant proteins to detect pathogen-specific antibodies. For instance, a study of patients suffering PJI used a selection of 16 recombinant proteins from 5 different bacterial species to determine serum IgG levels. Indeed, staphylococcal infections were identified with a sensitivity/specificity of $72.3 \%$ and $80.7 \%$, respectively (Marmor et al., 2016). In another study by Nishitani et al. (2015), where 14 protein candidates were tested in a patient cohort with $S$. aureus cultureconfirmed musculoskeletal infections, the $S$. aureus antigens IsdB and Hla showed the highest diagnostic value. Nevertheless, the authors recommended the use of a larger set of antigens, allowing for a higher sensitivity as compared to a single antigen.

To establish a reliable diagnostic assay, it would be necessary to identify immunogenic proteins that are conserved within a species of interest, to ensure optimal sensitivity and specificity. However, nosocomial infections, including sepsis, are usually caused by a multitude of different bacterial species. Furthermore, the immune proteome of some of those pathogens is often still enigmatic. This has prompted the exploration in the present study of a novel approach, where complex protein extracts from common sepsis pathogens were used to determine IgG binding in sepsis patients as well as healthy subjects, using a semi-automated quantitative immunoblot assay.

The humoral response to antigenic or inflammatory challenges, such as infection, vaccination or trauma, has been proposed to comprise the polyclonal activation of memory B cells of unrelated specificity (Bernasconi et al., 2002). Remarkably, in the absence of

\section{Plasma antibody binding}

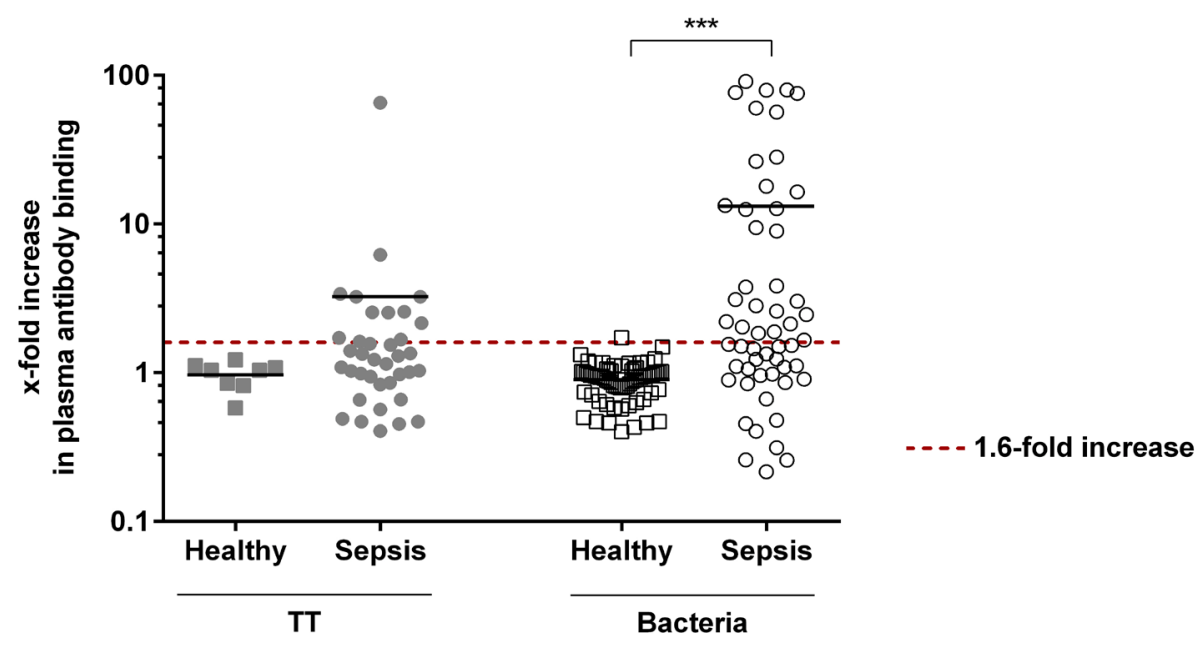

Fig. 2. Antibody kinetics in healthy subjects and sepsis patients. Plasma antibody binding to the recall antigen TT, as well as to extracellular proteins of frequent sepsis pathogens, was quantified using semiautomated quantitative immunoblotting. In patients, plasma antibody binding during infection was compared with that prior to the clinical diagnosis of sepsis using routinely reserved diagnostic samples. In healthy subjects, a comparable time period was investigated. In healthy subjects, the plasma antibodies specific for all tested antigens remained stable over time $(\Delta T=20 \mathrm{~d})$. The same was observed for the TTspecific antibody levels in sepsis patients $(\Delta \mathrm{T}=16 \mathrm{~d})$. In contrast, many sepsis patients showed a significant increase in plasma antibody binding directed against the diagnosed pathogen. Red lines mark the threshold of increase (mean $+3 \times \mathrm{SD}$; values of healthy subjects). Single squares (healthy subjects) and dots (sepsis patients) show the means of two replicate values; means are indicated. Healthy subjects and sepsis patients were compared using the unpaired $t$-test. ${ }^{* * *} p<0.001$. 
exposure to the recall antigen TT, a moderate increase in anti-TT IgG was found in patients following cardiothoracic surgery (Pötschke et al., 2012). Hence, to account for a possible non-specific $B$ cell activation in the study patient cohort, the anti-TT IgG response was also monitored. At first, IgG binding to 9 common sepsis pathogens (Table 2, group 1) was measured in the healthy control group (Fig. 1) and basal antibody a

Patient 10

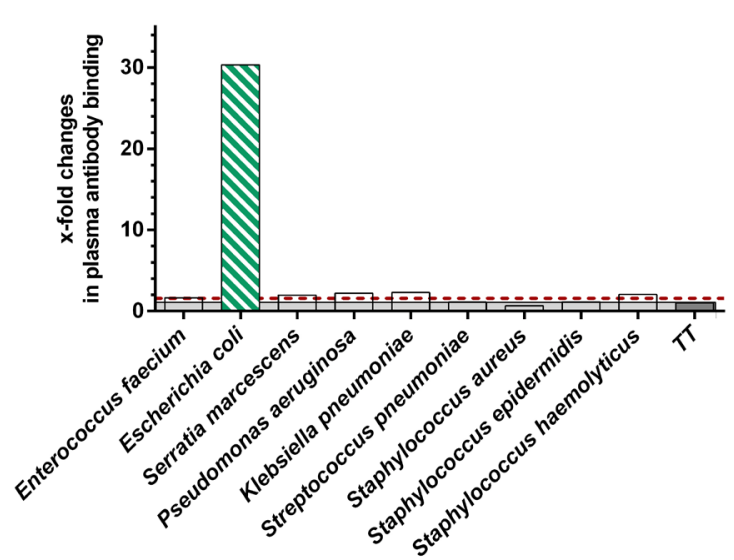

C

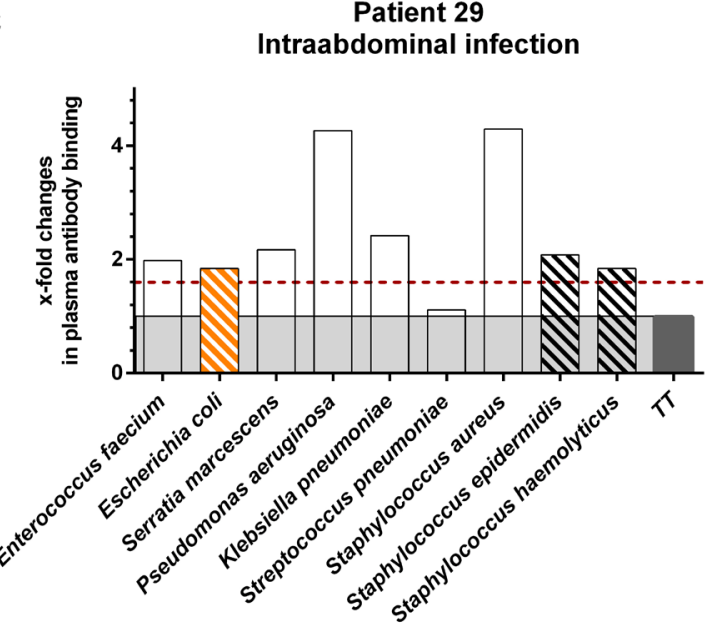

b

Patient 50

Intraabdominal infection

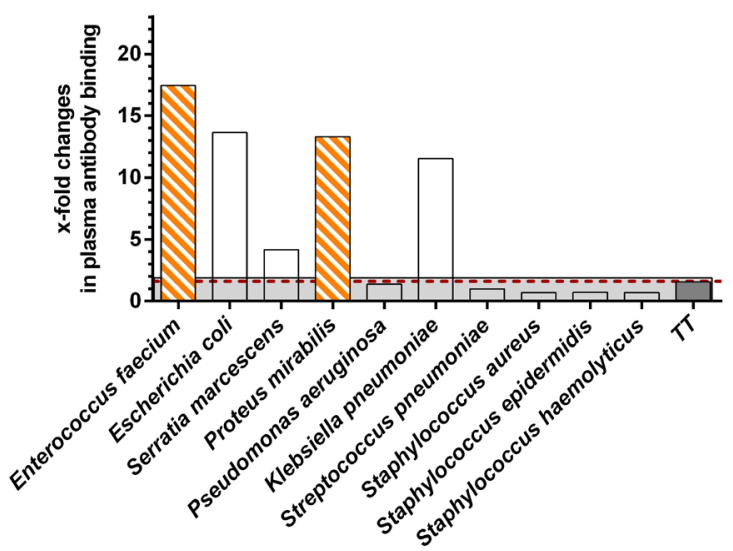

Pathogen diagnosed by:

NW PCR only

- - 1.6-fold increase

TT control

Fig. 3. Pathogen-specific antibody responses in sepsis patients. Plasma antibody binding to extracellular proteins of frequent sepsis pathogens was quantified using semi-automated quantitative immunoblotting. TT served as a control antigen. Plasma antibody binding during infection was compared with that prior to clinical diagnosis of sepsis. In patients showing an increase in plasma antibody binding directed against the diagnosed pathogen, plasma antibody binding to all 9 sepsis pathogens was determined. 3 typical cases are shown, where serology was consistent with the microbiological culture and PCR. (a) IgG binding was selectively increased to a single pathogen; (b) additional pathogens were identified by serology; (c) the strongest IgG response was caused by bacteria other than the microbiologically diagnosed ones. Red lines mark the threshold of increase (mean $+3 \times$ SD; values of healthy subjects, Fig. 2). Bars represent individual values. Colours indicate whether pathogens were diagnosed by microbiological culture [green, blood culture (BC); orange, other microbiological culture]; colour in combination with hatching indicates concordance of microbiological and PCR results; the grey area shows the response to the control antigen TT.

Table 3. Heatmap to visualise the increases in pathogen-specific and TT-specific antibody levels in the sera of all 20 sepsis patients who showed an increase. For each patient, the two time points of plasma sampling, at which the pathogen-specific IgG binding was determined, are shown. Furthermore, the increase in IgG response, the microbiological diagnosis and the focus of infection are listed. The patients are grouped according to the 3 typical cases mentioned in the text and shown in Fig. 3a-c. ND, not determined. 1ECOL (E. coli); ENTFA (E. faecalis); ENTFC (E. faecium); KLEO (K. oxytoca); KLEP (K. pneumoniae); PROM (P. mirabilis); PSEA (P. aeruginosa); SERM (S. marcescens); STAA (S. aureus); STAE (S. epidermidis); STAHA (S. haemolyticus); STAHO (S. hominis); STRP (S. pneumoniae). ${ }^{2} \mathrm{~B}$, primary bacteraemia; B/ST, bone and soft tissue infection; IA, intraabdominal infection; $\mathrm{P}$, pneumonia. 


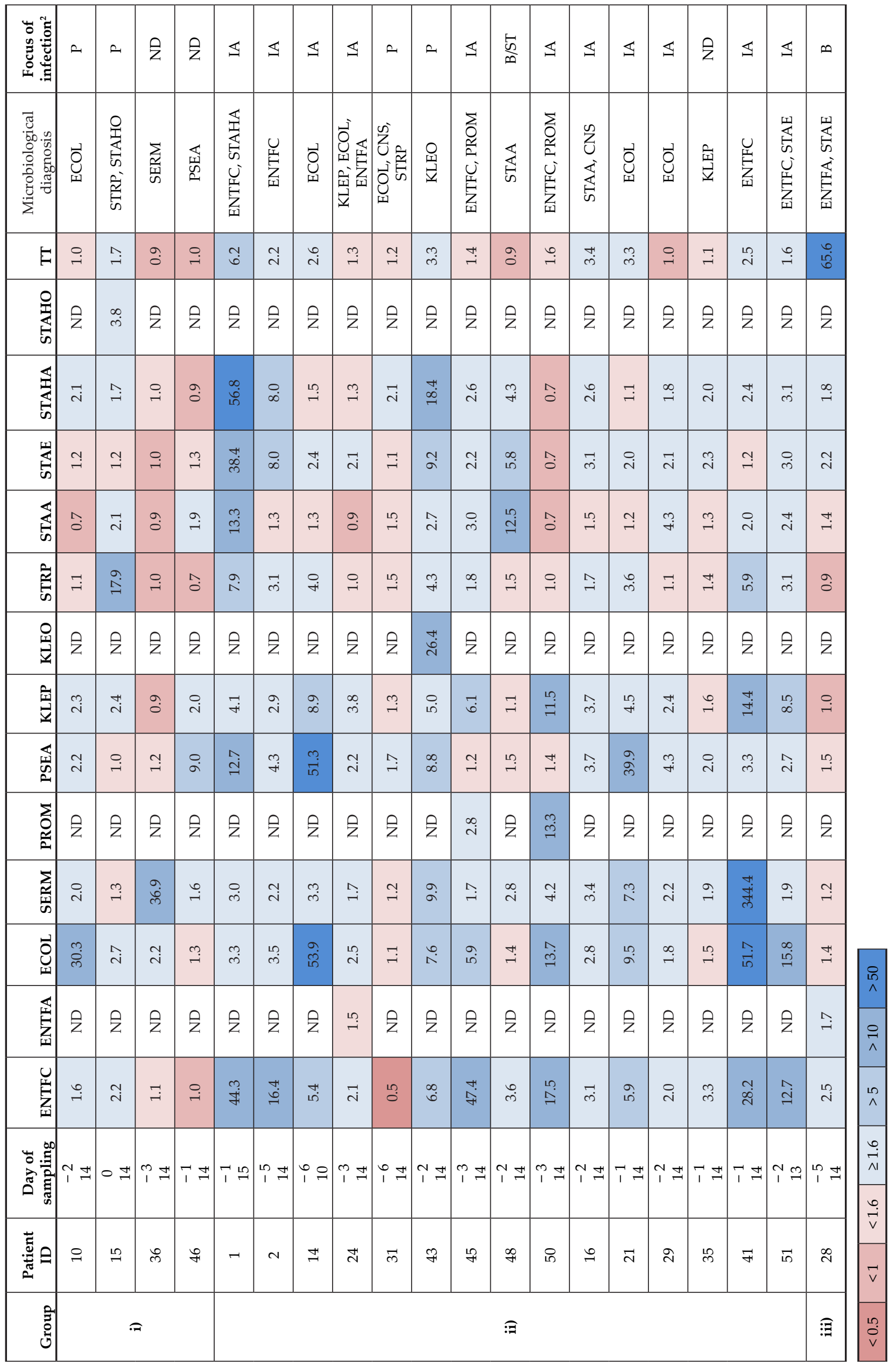


titers against all bacterial species were observed. The antibody titers showed a broad inter-individual variation but were generally higher for $S$. aureus. This could be explained by the ubiquitous nature of $S$. aureus, where humans are regularly exposed to this microorganism, often within the first hours of life (Maayan-Metzger et al., 2017; Verkaik et al., 2010). Therefore, S. aureus-specific IgGs are regularly observed in healthy adults, independent of their carrier status, albeit at highly varying concentrations (Wertheim et al., 2005). This was also reflected in the study healthy group, which comprised 6 S. aureus non-carriers, a persistent carrier and an intermittent carrier.

Sepsis is often caused by commensals or pathobionts, which belong to the physiological microbiota but can cause severe infection in immunocompromised hosts. Healthy humans gradually acquire systemic immune memory of those bacteria, which is reflected by the presence of specific IgG antibodies (Bröker et al., 2014). These are probably induced by repeated minor bacterial invasions (Macpherson et al., 2005), which explains the presence of specific antibodies in healthy adults, as well as the basal antibody levels among the patients included in the study. For instance, plasma antibodies could also be detected against the skin commensal S. epidermidis. The observation that S. epidermidis colonises humans more often than $S$. aureus but is less virulent and invasive (Massey et al., 2006) is consistent with the present study data (Fig. 1).

The anti-bacterial antibodies in healthy subjects were highly variable in terms of binding patterns and titers but changed little over time (Fig. 2 and Verkaik et al., 2009). On the other hand, the present study showed that in most sepsis patients, the specific IgG levels increased considerably during the course of the infection. Similar observations have been reported in patients with $S$. aureus bloodstream infection, where these increases in IgG titers were clearly driven by the invasive pathogen (Kolata et al., 2011). Many sepsis patients experienced a slight increase in antiTT IgG binding (Fig. 2). However, this was - except for one case (patient 28) - much lower than that of the anti-bacterial response, confirming the generation of a species-specific IgG response. When sepsis patients were tested for changes in IgG binding to 9 common sepsis pathogens, the response patterns were highly individual and discriminated between different infectious agents. In 4 patients, the increase in IgG was selective for 1 single microbiologicallydiagnosed pathogen. Interestingly, a case report has previously provided evidence that the anti-bacterial IgG response is even strain-specific. In an S. aureus carrier, the increase in antibody binding is specific for the extracellular proteins of the invasive clinical S. aureus isolate, rather than the colonising strain (Kolata et al., 2011). Although cross-reactions between related bacterial species are expected, especially when working with complex bacterial protein extracts, the comparison of increases in antibody titers against the three tested staphylococcal species often showed a dominant reaction against only one of them (Table 3). The same holds true for Gram-negative bacteria, where no obvious cross-reactivity among the different species was observed but rather, a speciesspecific immune response.

In the present proof-of-concept study, 20 out of 37 sepsis patients with a microbiological diagnosis developed a humoral immune response against the pathogen diagnosed by either microbial culture or PCR. Remarkably, in 15 of these patients there was an antibody response to additional undiagnosed bacteria. Consistent with the serological findings, most of those patients suffered from an intraabdominal infection due to gut perforation or surgical suture failure. Hence, the immunological approach was often more sensitive than conventional microbial culture-based diagnostics, indicating a poly-microbial infection. In patient 41 , for instance, E. faecium was microbiologically identified; however, the increase in IgG binding to $S$. marcescens exceeded that observed for the diagnosed pathogen by 10 -fold. This could have two explanations: either S. marcescens was the actual cause of infection or the basal anti-S. marcescens antibody levels were very low when compared to those against $E$. faecium. Since the baseline situation significantly influenced the magnitude of the calculated ratio, this could lead to an overestimation of the observed antibody increase for $S$. marcescens. It is worth mentioning that $S$. marcescens was diagnosed in the blood culture of a single patient (patient 36), but not by PCR. An immune reaction against pathogens undetected by microbiological diagnosis could explain cases of failed antimicrobial therapy despite a seemingly targeted selection of antibiotics.

The study further demonstrated that, while the pre-existing anti-bacterial antibody titers were highly variable (Fig. 1), increases in anti-bacterial IgG were indicative of an infection and specific to the infectious agent. Similar observations were made in children with musculoskeletal S. aureus infections. Although this young cohort presented with low basal anti-S. aureus antibody levels, the diagnostic power of antibody titer changes was higher than that of single measurements at diagnosis (Wood et al., 2018).

The present proof-of-concept study has some limitations. First, the healthy subjects were not strictly sex- and age-matched to the sepsis patients. Second, 17 out of 37 patients showed no increase in specific plasma IgG against the microbiologically diagnosed pathogen, which might be for various reasons:

- the microbiologically diagnosed pathogen did not cause the infection, but was merely a contaminant and, hence, did not elicit an immune response;

- at the first time point of antibody determination, the disease process was already too advanced to observe an appreciable increase;

- serum conversion occurred after the second blood sample was collected;

- the patients were unable to generate an efficient immune response due to immunosuppression; 
- the immediate initiation of an appropriate antibody therapy reduced the bacterial load so rapidly that no immune response was triggered. Nevertheless, the study clearly showed that a focus on the immunological host response to sepsiscausing agents can add valuable information to microbiological and molecular diagnostics, which target the pathogen. It offers several advantages over those established techniques that might warrant the implementation of this approach alongside routine diagnostics. For instance, it is often challenging to cultivate pathogens from biofilms of PJIs, where culture-based methods would require invasive surgery to access the pathogens. In such cases, a serological non-invasive approach would be of great benefit. Moreover, its readout is robust against antibiotic treatment and it can discriminate immunologically relevant infection from sample contamination.

In the future, efforts will be made to improve and optimise both the sensitivity and the selectivity of this approach, by supplementing the complex antigen mixtures with panels of recombinant species-specific antigens, in order to clearly distinguish between immune reactions against closely related species, such as S. aureus and S. epidermidis.

\section{Conclusion}

Increases in antibacterial antibodies provided valuable insights into the infection process. While in an acute infection the antibody response develops too late for early pathogen identification and guidance of the initial antibiotic treatment, it can help validate the diagnosis, especially in patients with chronic infections that often occur in association with indwelling medical devices/materials. The extent to which higher antibody titers against pathobionts provide clinical protection and could inform the development of immunisation strategies against pathobionts remains to be investigated.

\section{Acknowledgements}

We thank all patients and healthy controls for their participation. We thank the study nurses Liane Guderian and Manuela Gerber for their professional support.

This work was supported by the German Federal Ministry of Education and Research (BMBF) within the consortium InfectControl 2020 (Project TFP, grant ID 03ZZ0802K), the German Research Council (grant ID GRK-840; grant ID CRC-TRR34) and the European Union (European Social Funds, Card-ii-Omics, ESF/14-BM-A55-0037/16). The funding institutions had no role in study design, data collection and interpretation nor the decision to submit the work for publication.
We acknowledge support for the Article Processing Charge from the DFG (German Research Foundation, 393148499) and the Open Access Publication Fund of the University of Greifswald.

The authors have no conflicts of interest to declare.

\section{References}

Benito N, Mur I, Ribera A, Soriano A, RodríguezPardo D, Sorlí L, Cobo J, Fernández-Sampedro M, Del Toro MD, Guío L, Praena J, Bahamonde A, Riera M, Esteban J, Baraia-Etxaburu JM, Martínez-Alvarez J, Jover-Sáenz A, Dueñas C, Ramos A, Sobrino B, Euba G, Morata L, Pigrau C, Horcajada JP, Coll P, Crusi X, Ariza J (2019) The different microbial etiology of prosthetic joint infections according to route of acquisition and time after prosthesis implantation, including the role of multidrug-resistant organisms. J Clin Med 5: 1-15.

Bernasconi NL, Traggiai E, Lanzavecchia A (2002) Maintenance of serological memory by polyclonal activation of human memory B cells. Science 5601: 2199-2202.

Bradford MM (1976) A rapid and sensitive method for the quantitation of microgram quantities of protein utilizing the principle of protein-dye binding. Anal biochem 72: 248-254.

Bröker BM, Holtfreter S, Bekeredjian-Ding I (2014) Immune control of Staphylococcus aureus-regulation and counter-regulation of the adaptive immune response. Int J Med Microbiol 2: 204-214.

Byrd AL, Belkaid Y, Segre JA (2018) The human skin microbiome. Nat Rev Microbiol 3: 143-155.

Cohen J, Vincent J-L, Adhikari NKJ, Machado FR, Angus DC, Calandra T, Jaton K, Giulieri S, Delaloye J, Opal S, Tracey K, van der Poll T, Pelfrene E (2015) Sepsis: a roadmap for future research. Lancet Infect Dis 5: 581-614.

Dellinger RP, Levy MM, Rhodes A, Annane D, Gerlach H, Opal SM, Sevransky JE, Sprung CL, Douglas IS, Jaeschke R, Osborn TM, Nunnally ME, Townsend SR, Reinhart K, Kleinpell RM, Angus DC, Deutschman CS, Machado FR, Rubenfeld GD, Webb SA, Beale RJ, Vincent J-L, Moreno R, Surviving Sepsis Campaign Guidelines Committee including the Pediatric Subgroup (2013) Surviving sepsis campaign: international guidelines for management of severe sepsis and septic shock: 2012. Crit Care Med 2: 580637.

Fleischmann C, Hartmann M, Hartog CS, Welte T, Heublein S, Thomas-Rueddel D, Dennler U, Reinhart K (2015) Epidemiology of sepsis in Germany: incidence, mortality and associated costs of care 2007-2013. Intensive Care Med Exp 3 (Suppl 1): 1-2.

Fritz SA, Tiemann KM, Hogan PG, Epplin EK, Rodriguez M, Al-Zubeidi DN, Bubeck Wardenburg J, Hunstad DA (2013) A serologic correlate of protective immunity against community-onset Staphylococcus aureus infection. Clin Infect Dis 11: 1554-1561. 
Holtfreter S, Nguyen TTH, Wertheim H, Steil L, Kusch H, Truong QP, Engelmann S, Hecker M, Völker U, van Belkum A, Bröker BM (2009) Human immune proteome in experimental colonization with Staphylococcus aureus. Clin Vaccine Immunol 11: 16071614.

Hornef M(2015) Pathogens, commensal symbionts, and pathobionts: discovery and functional effects on the host. ILAR J 2: 159-162.

Kim HI, Park S (2019) Sepsis: early recognition and optimized treatment. Tuberc Respir Dis (Seoul) 1: 6-14.

Kolata J, Bode LGM, Holtfreter S, Steil L, Kusch H, Holtfreter B, Albrecht D, Hecker M, Engelmann S, van Belkum A, Völker U, Bröker BM (2011) Distinctive patterns in the human antibody response to Staphylococcus aureus bacteremia in carriers and non-carriers. Proteomics 19: 3914-3927.

La Suarez De Rica A, Gilsanz F, Maseda E (2016) Epidemiologic trends of sepsis in western countries. Ann Transl Med 17: 1-6.

Levy MM, Fink MP, Marshall JC, Abraham E, Angus D, Cook D, Cohen J, Opal SM, Vincent J-L, Ramsay G (2003) 2001 SCCM/ESICM/ACCP/ATS/SIS International sepsis definitions conference. Crit Care Med 4: 1250-1256.

Maayan-Metzger A, Strauss T, Rubin C, Jaber H, Dulitzky M, Reiss-Mandel A, Leshem E, Rahav G, Regev-Yochay G (2017) Clinical evaluation of early acquisition of Staphylococcus aureus carriage by newborns. Int J Infect Dis 64: 9-14.

Macpherson AJ, Geuking MB, McCoy KD (2005) Immune responses that adapt the intestinal mucosa to commensal intestinal bacteria. Immunology 2: 153-162.

Marmor S, Bauer T, Desplaces N, Heym B, Roux A-L, Sol O, Rogé J, Mahé F, Désiré L, Aegerter P, Ghout I, Ropers J, Gaillard J-L, Rottman M (2016) Multiplex antibody detection for noninvasive genuslevel diagnosis of prosthetic joint infection. J Clin Microbiol 4: 1065-1073.

Massey RC, Horsburgh MJ, Lina G, Höök M, Recker M (2006) The evolution and maintenance of virulence in Staphylococcus aureus: a role for host-tohost transmission? Nat Rev Microbiol 12: 953-958.

Michalik S, Sundaramoorthy N, Murr A, Depke M, Völker U, Bröker BM, Aamot HV, Schmidt F (2020) Early-stage Staphylococcus aureus bloodstream infection causes changes in the concentrations of lipoproteins and acute-phase proteins and is associated with low antibody titers against bacterial virulence factors. mSystems 1: 1-17.

Nishitani K, Beck CA, Rosenberg AF, Kates SL, Schwarz EM, Daiss JL (2015) A diagnostic serum antibody test for patients with Staphylococcus aureus osteomyelitis. Clin Orthop Relat Res 9: 2735-2749.

Oh I, Muthukrishnan G, Ninomiya MJ, Brodell JD, Smith BL, Lee CC, Gill SR, Beck CA, Schwarz EM, Daiss JL (2018) Tracking anti-Staphylococcus aureus antibodies produced in vivo and ex vivo during foot salvage therapy for diabetic foot infections reveals prognostic insights and evidence of diversified humoral immunity. Infect Immun 12: 1-11.

Pötschke C, Selleng S, Bröker BM, Greinacher A (2012) Heparin-induced thrombocytopenia: further evidence for a unique immune response. Blood 20: 4238-4245.

Sachse S, Straube E, Lehmann M, Bauer M, Russwurm S, Schmidt K-H (2009) Truncated human cytidylate-phosphate-deoxyguanylate-binding protein for improved nucleic acid amplification technique-based detection of bacterial species in human samples. J Clin Microbiol 4: 1050-1057.

Singer M, Deutschman CS, Seymour CW, ShankarHari M, Annane D, Bauer M, Bellomo R, Bernard GR, Chiche J-D, Coopersmith CM, Hotchkiss RS, Levy MM, Marshall JC, Martin GS, Opal SM, Rubenfeld GD, van der Poll T, Vincent J-L, Angus DC (2016) The third international consensus definitions for sepsis and septic shock (Sepsis-3). JAMA 8: 1-23.

Stentzel S, Sundaramoorthy N, Michalik S, Nordengrün M, Schulz S, Kolata J, Kloppot P, Engelmann S, Steil L, Hecker M, Schmidt F, Völker U, Roghmann M-C, Bröker BM (2015) Specific serum IgG at diagnosis of Staphylococcus aureus bloodstream invasion is correlated with disease progression. J Proteomics 128: 1-7.

Stentzel S, Vu HC, Weyrich AM, Jehmlich N, Schmidt F, Salazar MG, Steil L, Völker U, Bröker BM (2014) Altered immune proteome of Staphylococcus aureus under iron-restricted growth conditions. Proteomics 16: 1857-1867.

Trung NT, Thau NS, Bang MH, Le Song H (2019) PCR-based Sepsis@Quick test is superior in comparison with blood culture for identification of sepsis-causative pathogens. Sci Rep 1: 1-7.

van der Kooi-Pol MM, Vogel CP de, WesterhoutPluister GN, Veenstra-Kyuchukova YK, Duipmans JC, Glasner C, Buist G, Elsinga GS, Westra H, Bonarius HPJ, Groen H, van Wamel WJB, Grundmann H, Jonkman MF, van Dijl JM (2013) High antistaphylococcal antibody titers in patients with epidermolysis bullosa relate to long-term colonization with alternating types of Staphylococcus aureus. J Invest Dermatol 3: 847-850.

Verkaik NJ, Lebon A, Vogel CP de, Hooijkaas H, Verbrugh HA, Jaddoe VWV, Hofman A, Moll HA, van Belkum A, van Wamel WJB (2010) Induction of antibodies by Staphylococcus aureus nasal colonization in young children. Clin Microbiol Infect 8: 1312-1317.

Verkaik NJ, Vogel CP de, Boelens HA, Grumann D, Hoogenboezem T, Vink C, Hooijkaas H, Foster TJ, Verbrugh HA, van Belkum A, van Wamel WJB (2009) Anti-staphylococcal humoral immune response in persistent nasal carriers and noncarriers of Staphylococcus aureus. J Infect Dis 5: 625-632.

Wertheim HFL, Melles DC, Vos MC, van Leeuwen W, van Belkum A, Verbrugh HA, Nouwen JL (2005) The role of nasal carriage in Staphylococcus aureus infections. Lancet Infect Dis 12: 751-762.

Wood JB, Jones LS, Soper NR, Xu M, Torres VJ, Buddy Creech C, Thomsen IP (2018) Serologic 
detection of antibodies targeting the leukocidin LukAB strongly predicts Staphylococcus aureus in children with invasive infection. J Pediatric Infect Dis Soc 2018:00: 1-8.

Yamamoto Y (2002) PCR in diagnosis of infection: detection of bacteria in cerebrospinal fluids. Clin Vaccine Immunol 3: 508-514.

\section{Discussion with Reviewer}

Gowrishankar Muthukrishnan: What is the rationale for choosing an immunoblot assay as opposed to other approaches to assess IgG responses?

Authors: The Peggy Sue ${ }^{\mathrm{TM}}$ Simple Western Assay is a semi-automated quantitative immunoblotting that allows for the simultaneous analysis of up to 88 samples in a short time. Moreover, only small sample volumes are required, which is especially important when working with patient material. The results can be displayed as electropherograms, indicating the antibody binding profiles with information about the MW of the sample, or can be automatically transformed into area under the curve (AUC) for quantification. Therefore, the Peggy Sue ${ }^{\mathrm{TM}}$ Simple Western Assay is superior to an enzyme-linked immunosorbent assay (ELISA). Nevertheless, the assay has some limitations. Only one analyte can be measured at a time. In the future, we hope to improve the assay by using recombinant proteins of different pathogens and by using the Luminex technology to quantify the antibody response against several antigens simultaneously.

Editor's note: The Scientific Editor responsible for this paper was Fintan Moriarty. 